\title{
New Zealand's Bill of Rights: A Provisional Assessment
}

\author{
Wayne Mapp
}

\begin{abstract}
7 The enactment of the New Zealand Bill of Rights Act in 1990 is a major development of the constitutional history of New Zealand. Although the Bill of Rights Act is not strictly a constitutional statute in that it is not fundamental law, the rights and liberties contained within it are essential to any liberal-democratic society. ${ }^{1}$ In New Zealand such rights and liberties have traditionally been part of the fabric of the common law and constitutional custom.

The constitutional structure of New Zealand has, like that of the United Kingdom, lacked the formal mechanisms that prevent a determined executive from infringing the rights of citizens. The absence of a written constitution, along with a unicameral and relatively small parliament elected by a first-past-the-post electoral system, has led to an excessive concentration of power in the executive, which has typically consisted of almost half the members of parliament of the governing party. The scope for abuse has been substantial. However, the recently adopted proportional electoral system is likely to reduce the power of the executive.
\end{abstract}

\section{Origins of New Zealand's Bill of Rights}

New Zealand's Bill of Rights originated with the Labour governments of 1984-90. These included a new generation of parliamentarians who were committed to the promotion of individual political and economic freedom, largely in reaction against the economic authoritarianism of the preceding National government of Sir Robert Muldoon. Sir Geoffrey Palmer, initially the Deputy Prime Minister, and Prime Minister in 1989-90, had been a professor of constitutional law at Victoria University of Wellington and, in his 1979 study Unbridled Power, criticised the barely checked power of the state to curtail the rights of citizens. A Bill of Rights was viewed as a necessary defence of the citizen against the state.

The older democracies modelled on the Westminster system have not usually had Bills of Rights. This pattern was broken by Canada, which in 1960 enacted its first Bill of Rights, modelled closely on the United Nations Universal Declaration of Human Rights and the International Covenant on Civil and Political Rights. For

\footnotetext{
${ }^{1}$ Ministry of Transportv Noort [1992] a NZLR, 260; per Richardson J at 277. See also Sir Robin Cooke (1994:10): 'The New Zealand Bill of Rights Act 1990 is not entrenched or declaned to be supreme law.'
} 
common-law nations the United States Bill of Rights has perhaps had greater political and legal significance. However, unlike the United States Bill of Rights, the Canadian version did not override all other legislation but instead was an aid in the interpretation of legislation. This was changed in 1982, when the Bill of Rights was replaced by the Canadian Charter of Rights and Freedoms. Canadian courts now have the power to strike down any legislation that is in conflict with the Charter.

The Canadian experience spurred New Zealand legislators, led by Sir Geoffrey Palmer, in 1985 to promote a Bill of Rights for New Zealand. The initial proposal was for a Bill of Rights which included a wider range of political and economic rights. It also provided for the rights of the Maori people under the Treaty of Waitangi to be recognised and affirmed. The Bill of Rights was, like the Canadian Charter, to be a superior law overriding ordinary legislation. Yet the proposal proved to be unacceptable, for two reasons. First, a number of commentators, including National Party members of parliament, judged that giving the courts the power to overturn legislation would be contrary to the supremacy of parliament and thus represent an infringement of popular sovereignty; moreover, it was feared that if the courts had such a power they, and ultimately the appointment of judges, would become unduly politicised. Second, at a meeting of Maori tribal leaders in 1986, it was argued that incorporating the Treaty of Waitangi into a Bill of Rights would diminish the status of the Treaty as the founding constitutional document of New Zealand and enable parliament to amend the Treaty without the consent of the Maori treaty partner. As a result, the government modified its approach and introduced a new Bill of Rights, which, though more limited than its predecessor, failed to win the support of the National Party Opposition.

\section{The Provisions of the Bill of Rights}

The Bill of Rights enacted in 1990 is limited to the political rights generally accepted in modern western democracies. The protection of private property is excluded, largely on the ground that such protection does not easily fit within a document devoted to upholding political and civil rights. Elkind and Shaw (1986:7) argue that whereas political rights require governments to refrain from taking action, economic rights require them to take positive action. But in this respect the right to private property is more akin to political rights than to the economic rights to, say, housing or work, since the corresponding obligation on the state is not to take a positive action that would deprive rightful owners of their property. Moreover, Article 17 of the Universal Declaration of Human Rights provides that everyone has the right to own property and shall not be arbitrarily deprived of such property.

\footnotetext{
${ }^{2}$ In particular draft paragraph $10(2)$ referred to the right to join trade unions 'consistently with legislative provisions enacted to ensure effective trade union representation'. In 1985 trade union membership was compulsory for any category of employee covered by an award.

3

Rt Hon Geoffrey Palmer, Hansard, 3449 (1990).
} 
The principal rights protected by the Bill of Rights fall into four categories: the life and security of the person; democratic and civil rights; the right to nondiscrimination; and protection against arbitrary police powers of search, arrest and detention. The life and security of the person include the rights not to be deprived of life, not to be subjected to torture or cruel treatment, not to be subjected to medical experiments, and to refuse medical treatment. Democratic and civil rights include the rights to elect and to be elected a member of government, and the freedoms of thought, conscience, religion, belief, worship, expression, peaceful assembly, association and movement. New Zealand's history has given great importance to freedom from discrimination on grounds of colour, race, ethnic and national origin, sex, marital status and religious or ethical belief. Minorities have the right to their culture, language and religion. The final category of rights includes the right to security against unreasonable search and arbitrary arrest, the rights of arrested persons (including the right to legal counsel), the rights of persons charged and the right to trial before duly constituted courts. Whenever a person's rights are being affected by a tribunal the principles of natural justice are to be observed. The Bill of Rights applies to the legislative, executive and judicial branches of government and to any person or body performing a public function pursuant to law. The provisions of the Bill of Rights are to be subject only to such reasonable limits as are appropriate to a free and democratic society. In deference to the argument on the principle of parliamentary sovereignty, s.4 of the Bill of Rights Act provides that it does not override legislation that was or is specifically contrary to the provisions of the Bill of Rights Act. However, wherever possible legislation is to be interpreted in a manner that is consistent with the rights and freedoms of the Bill of Rights.

The Act was one of the last enacted by the Labour government of 1987-90. The Opposition considered that it added little to New Zealand's democracy. $\mathbf{M r}$ Paul East, the current Attorney-General, argued that the rights it spelt out already existed in the common law and were inherent in the respect for democratic values by New Zealand legislators. "The Prime Minister, in contrast, argued that the limited Bill of Rights being enacted would be a valuable first step along the road to a full Bill of Rights on the lines of the Chanadian Charter, which has the status of fundamental law overriding all other law.

\section{Effects on the Protection of Rights}

The Bill of Rights Act has been in force for over three years. Has it had a significant effect on the protection of individual rights? If so, should it be enacted as fundamental law on the model of the Canadian Charter? Australians may well

\footnotetext{
4

Hansard, 3457 (1990).

5 Hansard, 3449 (1990).
} 
ask if their Constitution would be enhanced by the inclusion of a Bill of Rights, particularly as the republican debate gathers force.

A review of the decisions of the courts in the first three years shows that the Bill of Rights is not a 'token and toothless thing' (Cooke, 1994:10). The President of the Court of Appeal is in no doubt as to the significance of the Bill of Rights:

More importantly, the Bill of Rights may be of prime influence in the shaping of the common law in areas hitherto grey or unexplored. Where any of the rights and freedoms affirmed in Part II and referred to in $\mathrm{s.2}$ are relevant, the developing common law must be moulded so as to give effect to them. (Cooke, 1994:11)

The majority of cases have concemed the right of persons to a lawyer when they have been detained or arrested. This right has been traditionally contained in the common law in The Judges Rules 1912 but is now set out in unequivocal terms in $\mathrm{s}$. 23(1)(b) of the Bill of Rights Act. The initial decisions of the Courts were somewhat tentative in applying the Act in a manner that would contradict traditional practice. Thus in $R \mathrm{v} N$ Nikau ${ }^{6}$ Wylie J, in relation to the meaning of arrest, noted:

The New Zealand Bill of Rights Act does not give a warrant to alter longstanding principles of law. It may be, undoubtedly is, declaratory of rights, but that does not of itself justify an overturning of principles which have become enshrined in the law of the country over a long period of years.

This statement was cited with approval by Gault $J$ in the Court of Appeal decision of $R \mathrm{v}$ Butcher with 'the qualification that the Courts necessarily will be required to adopt and develop interpretations and remedies appropriate to this significant statute. ${ }^{8}$

In the last two years the Court of Appeal has become emboldened in its response to the Bill of Rights. Arguably the most important case to date is Ministry of Transport $\mathrm{v}$ Noort ${ }^{9}$ The case concerned the rights of persons apprehended pursuant to the Transport Act and who are required to accompany an officer to give breath or blood tests. The Court had no doubt that this constituted a detention within the meaning of $s .23(1)(b)$ and therefore raised the presumption that the person was entitled to have access to a lawyer. The President of the Court of

${ }^{6}$ AuckJand, T 45/91, 23 April 1991.

${ }^{7}$ [1992] 2 NZLR 257, 271

${ }^{8}$ Id. 271.

9 [1992] 3 NZLR, 260. The Court consisted of five judges; Cooke P, Richardson, Hardie Boys and McKay JJ; Gault J dissenting. The majority found in favour of Noort. 
Appeal had no doubt that the Bill of Rights required a new approach. Cooke P stated:

[T]he Act requires development of the law where necessary. Such a measure is not to be approached as if it did no more than preserve the status quo. . . In approaching the Bill of Rights Act it must be of cardinal importance to bear in mind the antecedents. The International Covenant on Civil and Political Rights speaks of inalienable rights derived from the inherent dignity of the human person. Internationally there is now recognition that some human rights are fundamental and anterior to any municipal law, although municipal law may fall short of giving effect to them: see Mabo v Queensland (1988) 166 CLR 186, 217-218. The right to legal advice on arrest or detention under any enactment may not be quite in that class, but in any event it has become a widely recognised right.

Each of the judges specifically stated that the Bill of Rights Act is not a constitutional statute. However, all the judges, including the dissenting judge, recognised the significance of the rights protected. Thus Richardson J (one of the majority) stated:

It is not a constitution. It is not supreme law in that sense. It does not override all other legislation. Nevertheless in interpreting and applying the Act it is important to consider the nature and subject-matter and special character of the legislation.

The dissenting judge, Gault J, was no less vigorous in upholding the primacy of the Bill of Rights:

The fundamental rights affirmed in the Bill of Rights Act are to be given full effect and are not to be narrowly construed. Its provisions are to be construed to ensure its objects of protecting and promoting human rights and fundamental freedoms. It is a statute, not an entrenched constitutional document, but it is couched in broad terms requiring interpretation appropriate to those objects. Its terms, in large measure, have been drawn from the Canadian Charter of Rights and Freedoms so that Canadian decisions can be expected to assist in interpretation so long as there is borne in mind the different status enjoyed by the Charter.

10

Id. 270. Cooke $\mathbf{P}$ had previously noted the submission by counsel for the Crown that "the New Zealand Courts should not adopt what they called "the rhetoric" of some Canadian Supreme Court judgements'(p.269).

11

Id. 277.

12

Id. 292. 
The application of the Bill of Rights to drink-drive cases was perhaps unanticipated by both the public and politicians. It certainly indicated the importance of the Bill of Rights in limiting the ad hoc encroachment of civil rights for administrative convenience. Without such an enactment it would have been very much more difficult for the Courts to import a requirement of access to a lawyer into the bloodalcohol provisions of the Transport Act.

In cases involving more serious crimes the Bill of Rights has been routinely invoked. The Court of Appeal has taken the opportunity to signify the importance of the rights protected. The case of $R \mathrm{v}$ Narayan ${ }^{13}$ concerned the admissibility of police interviews of a person accused of murder. He had a limited command of English and an Indian police constable acted as his interpreter and custodial escort. The Court was satisfied that the interviews took place in circumstances where the accused would have reasonably thought he had been detained. He was therefore entitled to access to counsel pursuant to s.23(1)(b) of the Bill of Rights Act. Cooke P stated:

But the answer made for the accused is in effect that for a man in his situation, with language difficulties and in an alien country and having undergone something of an ordeal, the rights given by the New Zealand Bill of Rights Act were of special value; and that he should not be deprived of their value merely because the police acted in good flith.

In a similar case, $R \mathrm{v}$ Mallison, ${ }^{15}$ the accused was arrested but not told of his right to a lawyer until an hour later. Richardson J held:

The Bill of Rights Act is not a technical document. It has to be applied in our society in a realistic way.

The Court considered that the police had sufficient opportunity to advise the accused of his right to counsel at the time of arrest.

The consequences of failing to comply with the requirements of the Bill of Rights Act can be severe. In both these cases the Court of Appeal excluded the statement made by the accused and ordered a new trial.

The Court of Appeal has also considered the nature of right of free speech guaranteed by s.14 of the Bill of Rights Act in TV3 Network Services Ltd $v$. $^{17}$ This case concerned the right of the television station to publish by consent the

\footnotetext{
13

[1992] 3 NZLR, 145.

${ }^{14}$ Id. 149 .

${ }^{15}$ [1993] 1 NZLR, 528

16

Id. 531.

,

[1993] 3 NZLR, 421.
} 
names of two victims in a notorious incest case. This would have lead to the identification of other victims who had not consented. The Criminal Justice Act generally prohibits such identification. Cooke $P$ stated:

It is true that freedom of expression, both by the media and in this case by the two consenting sisters, is a factor the importance of which is underlined by s.14 of the New Zealand Bill of Rights Act 1990, but in the circumstances of the present case freedom of expression is to be subordinated to the public policy indicated by Parliament under s.139(2). By virtue of s.4 of the New Zealand Bill of Rights Act that policy must prevail over s.14.

The latter sentence indicates the limitations of a statute which is not fundamental law.

\section{Conclusions}

The provisional answer to the primary question of whether the Bill of Rights has been a substantial additional protection of basic human rights must be in the affirmative. The courts have been zealous in enforcing the Bill of Rights, particularly where the exercise of police powers is concerned, which has been the traditional arena for the contest between the freedom of the individual and the powers of the state. The Bill of Rights Act has given the judiciary the opportunity to expound and expand upon the nature of fundamental rights, especially those concerning police powers, as the bedrock of a democratic society in a manner not previously witnessed in New Zealand. The President of the Court of Appeal has been open in his view of the expanded role of the Court of Appeal as the protector of both civil rights set out in the Bill of Rights Act and the rights of Maori contained in the Treaty of Waitangi.

In other areas the role of the Bill of Rights is somewhat limited. In the area of the encroachment by the state into the economic activity of citizens, for example, the Bill of Rights has offered little protection. This is reflected in the Privy Council decision in New Zealand Stock Exchange v Commissioner of Inland Revenue. The Privy Council, relying on a Canadian precedent, would not proscribe the

18

Id. 423.

19

Cooke (1994), The Treaty of Waitangi is now widely regarded as New Zealand's most important constitutional document; Cooke P, Special Waitangi Number: Introduction (1990) 14 NZULR, 1. The Court of Appeal has played a major part in the elevation of the Treaty of Waitangi as the founding constitutional document. See especially New Zealand Maori Council v Attomey General [1987] 1 NZLR, 641,643 where Cooke $P$ in the opening sentence to his judgement states: 'This case is perhaps as importantfor the future of our country as any that has come before a New Zealand Court' 20

[1992] 3 NZLR 1. The case concerned the application of s.23 of the Bill of Rights Act on the prohibition of 'unreasonable search and seizure' of person, their property and correspondence. 
Commissioner of Inland Revenue's powers to investigate taxpayers in the absence of express provision in the revenue acts. The Privy Council, in a unanimous judgement stated:

Having regard to the secrecy provisions of the Act of 1974 and to the fact that in the interests of the community the commissioner is charged with ensuring that the assessable income of every taxpayer is assessed and the tax paid, the 'search' involved in the application of s.17 cannot be said to be unreasonable.

The Privy Council also relied on the decision of the Supreme Court of Canada of Mckinlay Transport Ltd $v R^{22}$ which set out the 'different expectations of privacy in different contexts'.

It is suggested that apart from the expressed reasons, there are two additional fundamental, although unarticulated, reasons for the Privy Council's decision. The first is that the Bill of Rights Act does not include a counterpart to Amendment V of the United States Constitution providing that 'private property shall [not] be taken for public use without just compensation'. The second reason arises from the relative reluctance of the Courts to provide a theoretical justification for limiting the encroachment of the state into the economic affairs of citizens. In contrast to the Privy Council's decision allowing wide ranging powers of 'search' for the economic purposes of the state, the Court of Appeal, dealing with a classic exercise of police powers against the person, has readily imported the provisions of the Bill of Rights into the Transport Act which set out the procedures of the police in breath and blood-alcohol testing of motorists, notwithstanding that the Transport Act made no reference to the Bill of Rights Act.

The role of the Bill of Rights in the Constitution is not simply a question of whether it is declared to be supreme law. The content of the Bill of Rights must also be considered. The linkage between a citizen's effective exercise of political rights and the ability of people to organise their economic activities in accordance with market principles is now well accepted. It is hard to imagine a democratic society where all property is owned by the state.

The inclusion of Amendment $\mathrm{V}$ in the United States constitution has not limited the ability of the United States to develop a sophisticated government able to meet the needs of its citizens, although arguably this required the addition of Amendment XVI in 1895 giving the Congress the power to impose income taxes. Nevertheless, the United States has been spared the excessive encroachment of the state into the economic affairs of citizens that was so attractive to so many western democratic nations during the middle years of this century. At times it seemed that the United States was the only western nation that zealously protected the virtues of

\footnotetext{
${ }^{21}$ Id. 6.

22

(1990) 90 DTC 6,243 at 6,249.
} 
free and open markets. In particular the United States did not attempt to nationalise large sectors of the economy. Government has expanded by developing such policy areas as health care, tertiary education, public housing, energy, especially nuclear, and modern transportation. ${ }^{23}$ The regulatory powers of the state has been of greater significance in limiting the rights of private property. ${ }^{24}$ In contrast to other western states, the US constitution, in both its educative role and its enforcement by the courts, has had an essential role in clearly delineating the limits of state encroachment upon the political and economic liberties of citizens.

In the event that Australia enacts a Bill of Rights as part of its constitution, it may consider that the United States experience is as least as instructive as that of Canada and New Zealand, and enact a complete Bill of Rights rather than one limited to political rights. The value of the New Zealand experience is that Australians can be reasonably assured that the courts would give full force and effect to the protections contained within a Bill of Rights whether or not it is entrenched as supreme law. Once enacted there is no real likelihood that politicians will be able to nullify a Bill of Rights, although that will not prevent the continuing evolution of government within a democratic framework.

\section{References}

Cooke, R. (1994), 'A Sketch from the Blue Train: Non-discrimination and freedom of expression: the New Zealand Contribution', New Zealand Law Journal, January: $10-17$.

Elkind, J. \& A. Shaw (1986), A Standard for Justice: A Critical Commentary on the Proposed Bill of Rights for New Zealand, Oxford University Press, Auckland.

Epstein, R. (1985), Takings: Private Property and the Power of Eminent Domain, Harvard University Press, Cambridge, Mass.

$\mathbf{2}$

There is a much greater tendency in the United States for the government to fund economic activities that are perceived to be in the public interest rather than to both fund and provide or own the activity as is common in other western states: c.f. medicare, bank deposit guarantees, energy, and arms manufacturing (aerospace).

24

Richard Epstein has been an iconoclastic defender of the protections of the Amendment $V$ and has decried what he considers the excessive encroachment by the state upon the rights of private property. See Epstein (1985). 